\title{
SPI1 Gene
}

National Cancer Institute

\section{Source}

National Cancer Institute. SPI1 Gene. NCI Thesaurus. Code C18553.

This gene plays a role in transcriptional activation, cellular development and hematopoiesis. 